\title{
HEALTH PROMOTION - THE RATIONALE AND THE OBSTACLES IN WORKPLACES WITH DIFFERENT EMPLOYMENT AND FINANCIAL SOUNDNESS
}

\author{
PROMOCJA ZDROWIA - POWODY REALIZACJI ITRUDNOŚCI W JEJ WDRAŻANIU \\ W FIRMACH O RÓŻNEJ WIELKOŚCI ZATRUDNIENIA I KONDYCJI EKONOMICZNEJ
}

Nofer Institute of Occupational Medicine / Instytut Medycyny Pracy im. prof. J. Nofera, Łódź, Poland

National Centre for Workplace Health Promotion / Krajowe Centrum Promocji Zdrowia w Miejscu Pracy

\begin{abstract}
Background: This paper presents the prevalence of health promotion in workplaces in Poland. It characterises the undertaken actions, their rationale and perceived obstacles. It analyses the diversity of these phenomena in the companies of different financial soundness and level of employment. Material and Methods: The study was conducted with the use of Computer Assisted Telephone Interview in 2010 on the representative national sample of 1002 workplaces hiring more than 50 employees. The data was compared with the results of the survey conducted in 2006, with the use of a Paper and Pencil interview on 611 similar companies. Results: Both studies have shown that $40 \%$ of the companies are concerned about their employees' health to a greater extent than they are obliged to by the law. At the same time, more than $80 \%$ of the companies have been introducing various modifications and health-oriented actions without definite health intentions. Most companies improve their physical working environment, organise/sponsor medical services, sports activities and try to reduce stress and smoking. Managers have increased their awareness of business benefits received from health promotion. They have displayed more personal involvement in health promotion implementation. The most often mentioned obstacles have included limited financial resources and little interest of employees regarding health issues. Conclusions: The larger and wealthier the company is, the more often health promotion in the company is performed. Such a company is more convinced about an increase in its activities and has more reasons to care about health. Unequal access to health promotion of workers in different companies may contribute to an increase in health inequalities in the working population. Med Pr 2013;64(6):743-754
\end{abstract}

Key words: workplace, occupational health, health promotion, Poland

\section{STRESZCZENIE}

Wprowadzenie: W artykule przedstawiono stopień rozpowszechnienia promocji zdrowia w zakładach pracy w Polsce, scharakteryzowano podejmowaną aktywność, powody jej realizacji oraz wskazywane przeszkody. Pokazano zróżnicowanie tych zjawisk w firmach o różnej kondycji ekonomicznej oraz wielkości zatrudnienia. Materiał i metody: Badanie przeprowadzono w oparciu o wywiad telefoniczny standaryzowany, wspomagany komputerowo (Computer Assisted Telephone Interview - CATI) w $2010 \mathrm{r}$. w ogólnopolskiej próbie reprezentatywnej 1002 zakładów pracy, w których zatrudniano powyżej 50 pracowników. Dane zostały porównane z wynikami sondażu z 2006 r., przeprowadzonego metodą standaryzowanego wywiadu bezpośredniego (Paper and Pencil Interview - PAPI) wśród 611 podobnych firm. Wyniki: Oba badania pokazały, że $40 \%$ firm troszczy się o zdrowie personelu w większym stopniu, niż wymaga tego prawo. Jednocześnie ponad $80 \%$ wprowadza zmiany i działania sprzyjające zdrowiu, nie wiążąc ich intencjonalnie ze zdrowiem. Najwięcej firm doskonali fizyczne środowisko pracy, organizuje/sponsoruje usługi medyczne, zajęcia sportowe, próbuje redukować stres oraz palenie tytoniu. Wśród menadżerów wzrosła świadomość biznesowych korzyści z promocji zdrowia, częściej też osobiście angażują się w jej wdrożenie. Najczęściej wskazywane przeszkody w realizacji działań to ograniczone środki finansowe i małe zainteresowanie pracowników zdrowiem. Wnioski: Im większa i bogatsza firma, tym częściej prowadzona jest w niej promocja zdrowia i obecne jest przekonanie, że robi się więcej niż kilka lat temu, wskazywanych jest też więcej powodów tych działań. Nierówny dostęp do promocji zdrowia pracowników firm o innej wielkości zatrudnienia i kondycji ekonomicznej może przyczyniać się do wzrostu różnic w stanie zdrowia w populacji pracujących. Med. Pr. 2013;64(6):743-754

Słowa kluczowe: miejsce pracy, zdrowie pracujących, promocja zdrowia, Polska

Corresponding author / Autor do korespondencji: Krzysztof Puchalski, National Centre for Workplace Health Promotion, Nofer Institute of Occupational Medicine, św. Teresy 8, 91-348 Łódź, e-mail: puchal@imp.lodz.pl

Received: 2013, November 6, accepted: 2013, December 12

The study was funded under a subsidy from the Ministry of Science and Higher Education for the statutory activities of the Nofer Institute of Occupational Medicine. The findings were compiled under subject IMP 7.1/2011 "Anti-smoking activities undertaken by workplaces in Poland, in the context of amendments to the Act on the protection of health against the consequences of tobacco use". Subject manager: Krzysztof Puchalski, PhD. 


\section{INTRODUCTION}

In political declarations and theoretical deliberations on the topic, workplaces are regarded one of the key environments for implementing health promotion $(1,2)$. This is supported by a number of arguments associated both with the objectives of public health and the companies' interests (3-6). However, as shown in the research by the Nofer Institute of Occupational Medicine, conducted since 2000 on a sample of companies with over 50 employees (7-9), and their medical partners (10-12), the prevalence and quality of such efforts leave much to be desired. This results both from the companies' attitude towards health promotion and the deficiencies in state policies in this field (2).

Health promotion at a workplace can assume diverse meanings (13-15), being usually understood in a very broad way and defined through its goals and/or operating methods. From a more formal point of view, health promotion covers all of the initiatives a company undertakes with a view to its personnel's health, that are not imposed on the employer by external legal regulations (especially those pertaining to Occupational Health and Safety and occupational medicine). These non-mandatory actions may complement the adopted legal solutions (e.g. instructing employees on the dangers of exposure to cigarette smoke, upon the introduction of a statutory ban on smoking on company premises) or constitute autonomous undertakings (e.g. arranging sports activities for the personnel).

This paper aims at presenting:

the prevalence of companies' initiatives in the field of health promotion understood as defined above,

the specific features of the undertaken initiatives,

the motivation behind health promotion initiatives, the encountered difficulties.

The data come from a survey conducted in Poland in 2010 (i.e. before the peak of the global economic crisis) and cover a state of affairs in the sampled companies throughout the two years preceding the survey. Its findings will be juxtaposed with those from a similar study from 2006, when economic forecasts were still promising (16). It can be, thus, assumed that good financial soundness is conducive to companies' activity in health promotion, whereas a decline in this respect has an opposite effect. Hence, on the basis of 2010 results, this paper discusses a problem on whether the companies' financial soundness (established by way of self-assessment) differentiates the discussed phenom- ena. The analysis will also touch on differences related to the number of employees.

\section{MATERIAL AND METHODS}

The survey was carried out in late November / early December 2010, and covered 1002 workplaces (companies and institutions) countrywide, employing more than 50 people (excluding establishments involved in healthcare and education, according to the Polish Classification of Activities). The sample was selected randomly (from the database of Kompass Poland Sp. $z$ o.o.) being representative of all such companies operating in Poland. The stratified sampling scheme included voivodeships, industries and employment level categories. Of the analysed sample, organisations with 50 to 100 employees made up 30\%, 101-500 employees $60 \%$, while organisations employing 501-1000 and over-1001 people both accounted for $5 \%$ of the whole sample.

Within the sample, $13 \%$ of entities assessed their financial soundness over the previous 2-year period to be very good, $50 \%$ deemed it rather good, $31 \%$ - thought it varied, and $6 \%$ stated rather poor or very poor. The larger the company, the significantly more often it had good financial soundness (i.e. one in eleven among the smallest companies, and one in three among the largest), with fewer cases of the varied or poor financial soundness $\left(\chi^{2}=31.9 ; \mathrm{p}<0.0002\right)$.

The survey was conducted with the use of Computer Assisted Telephone Interviews (CATI), based on a standardised questionnaire with categorised questions, prepared by the National Centre for Workplace Health Promotion at the Nofer Institute of Occupational Medicine in Łódź, Poland (as a revised version of the tool employed in the survey of 2006 and postal questionnaires of 2000 and 2001). The respondents were selected from among senior corporate staff (members of the board / the management or their appointed representatives - usually managers in charge of the HR structure, occupational safety, etc.). The adopted unit of enquiry was a workplace, and, thus, one survey was conducted at each facility. The field survey was carried out by BBS Obserwator, a Kraków-based company.

Earlier, in 2006, building on the aforementioned questionnaire, another survey took place, by way of a Paper and Pencil Interview (PAPI). It covered 611 companies serving as a representative sample for all such entities in Poland (excluding those trading in health- 
care and education, according to the Polish Classification of Activities), employing more than 50 people. A stratified sampling scheme for workplaces included voivodeships and employment level categories. The sample had a structure similar to that analysed in 2010, i.e. with a slight majority of the smallest and the largest entities and a lower share of those employing 101-500 people; it also comprised more enterprises regarding their financial soundness as very good or rather good (differences in the respective categories hovered within a range of several percentage points). As in the more recent survey, the respondents again belonged to management staff. The field part was conducted by PBS DGA Sp. z o.o. in Sopot.

Any juxtapositions between the findings of both presented surveys should be approached cautiously due to slight methodological differences (a personal versus a telephone interview). However, since the data provided in this article constitutes the only representative source of information on the enterprises of this size in Poland, it seems worth juxtaposing them, even if this should not produce accurate results. To give greater credence to this comparative analysis, it should be noted that similar tendencies related to the level of employment and financial soundness, as compared to those described later in reference to 2010, can also be revealed (though less explicitly) in materials from an earlier study, not discussed here.

The analysis of the statistical significance of differences in the examined phenomena, connected with the number of employees and financial soundness, was verified with Pearson's $\chi^{2}$ test. The degree of differences was illustrated in the text by juxtaposing percentage values in respective categories (where such differences proved significant).

\section{RESULTS}

\section{The prevalence of non-mandatory initiatives in the field of personnel health promotion}

Around $60 \%$ of companies in both surveys stated that their care about their employees' health was confined to meeting the legal requirements in this area, whereas $40 \%$ declared they did more than that (Table 1).

Worth noting is the fact that, in 2010, $86 \%$ of the respondents agreed that a good company should exercise more care about their employees' health than it is required by the law ( $78 \%$ in the previous survey). Furthermore, $31 \%$ of the respondents believe that their company is now more willing to engage in health promotion initiatives than a few years back ( $26 \%$ in the previous survey). In addition, more entities (31\% versus 20\%) declared that they had their own personnel health policies laid down in an internal document (a collective labour agreement, labour regulations, dispositions, etc.).

The better companies assess their financial soundness, the more often systematically they declare themselves as caring about their employees' health to a degree broader than it is required by the law (Table 2). In addition, they are more likely to state that their involvement in health-related issues is deeper than a few years earlier. This is the opinion of the $40 \%$ of the best performing companies, dropping to $21 \%$ among those with the poorest financial soundness $\left(\chi^{2}=25.31\right.$; $\mathrm{p}<0.002$ ). At the same time, economic standing is not related to the possessing by a company of a documented internal health-promotion policy.

The larger the company, the more often systematically it engages in non-mandatory health promotion (Table 2). The growth in size was also accompanied by more declarations of increased involvement in health-related issues over recent years - this was the case with $26 \%$ among the

Table 1. The implementation of mandatory and non-mandatory actions for promoting the health of the personnel in companies in 2006 and 2010

Tabela 1. Realizacja obligatoryjnych i nieobligatoryjnych działań na rzecz zdrowia personelu w firmach w latach 2006 i 2010

\footnotetext{
"How would you describe the current situation in the company, concerning the health of its personnel?"

„Jak można określić aktualną sytuację w firmie, dotyczącą troski o zdrowie personelu?’
}

\begin{tabular}{cc}
\multicolumn{2}{c}{$\begin{array}{c}\text { Companies } \\
\text { Firmy } \\
{[\%]}\end{array}$} \\
\multicolumn{2}{c}{$[\%$} \\
$2006 \quad 2010$ \\
$=611) \quad(\mathrm{N}=1002)$
\end{tabular}

59

61

The company performs only those actions for the health of personnel which are required by the current law / Firma realizuje tylko te działania na rzecz zdrowia personelu, które wymagane są w aktualnie obowiązujących przepisach

In addition to the implementation of the legal requirements, the company is taking additional steps for improving the health of its personnel / Oprócz realizacji wymagań prawnych firma podejmuje także dodatkowe działania na rzecz zdrowia personelu
41

39 
Table 2. The implementation of non-mandatory actions for the health of personnel and the financial soundness and level of employment in companies in 2010

Tabela 2. Realizacja nieobligatoryjnych działań na rzecz zdrowia personelu a sytuacja ekonomiczna firm i wielkość zatrudnienia w $2010 \mathrm{r}$.

\begin{tabular}{lc}
\hline \multicolumn{1}{c}{$\begin{array}{c}\text { Characteristics } \\
\text { Charakterystyka }\end{array}$} & $\begin{array}{c}\text { Actions in companies } \\
\text { Działania w firmach } \\
(\mathrm{N}=1002) \\
{[\%]}\end{array}$ \\
\hline $\begin{array}{l}\text { Financial soundness / Sytuacja ekonomiczna } \\
\text { rather poor and very poor / raczej słaba i bardzo słaba }\end{array}$ & 24 \\
variable and difficult to assess / zmienna i trudna do oceny & 31 \\
rather good / raczej dobra & 39 \\
very good / bardzo dobra & 56 \\
Level of employment [people] / Wielkość zatrudnienia [osoby] & $5.0000(29.96)$ \\
$50-100$ & 28 \\
$101-500$ & 41 \\
$501-1000$ & 55 \\
$>1001$ & 60 \\
\hline
\end{tabular}

smallest and $48 \%$ among the largest entities $(\mathrm{p}<0.02)$. The company's size was a weak differentiation factor as regards a formal entry in the company's internal documentation - only among the largest entities were such entries more frequent than among the rest of the sample.
The content of initiatives in the field of health promotion

Table 3 does not show mere declarations, but specifically detailed health-related actions which, while not required by the law, were put in place in the surveyed

Table 3. Non-mandatory health-oriented actions in companies in 2006 and 2010

Tabela 3. Nieobligatoryjne działania prozdrowotne w firmach w latach 2006 i 2010

\begin{tabular}{|c|c|c|}
\hline $\begin{array}{c}\text { Actions } \\
\text { Działania }\end{array}$ & \multicolumn{2}{|c|}{$\begin{array}{l}\text { Companies } \\
\text { Firmy } \\
{[\%]}\end{array}$} \\
\hline $\begin{array}{l}\text { Attention to visual appearance, comfort and access to common areas (canteens, toilets, etc.) significantly exceeding current } \\
\text { standards and renovations / Dbałość o estetykę, wygodę i dostępność pomieszczeń socjalnych (jadalni, łazienek itp.) } \\
\text { znacząco wybiegająca ponad obowiązujące normy oraz bieżące remonty }\end{array}$ & 53 & 67 \\
\hline $\begin{array}{l}\text { Health-oriented job modifications exceeding health and safety regulations (e.g. reducing noise levels to that significantly } \\
\text { below the norm) / Poprawa warunków zdrowotnych na stanowiskach pracy ponad wymagania przepisów bhp } \\
\text { (np. redukcja hałasu znacząco poniżej normy) }\end{array}$ & 36 & 50 \\
\hline Vaccinations (e.g. influenza and hepatitis) / Szczepienia, np. przeciw grypie, wirusowemu zapaleniu wątroby & 47 & 47 \\
\hline $\begin{array}{l}\text { Changes in organisation and management to reduce work-related stress / Zmiany w organizacji i zarządzaniu w celu } \\
\text { redukcji stresu w pracy }\end{array}$ & 27 & 31 \\
\hline $\begin{array}{l}\text { Treatment or rehabilitation services funded by the company (e.g. cardiologist, dentist, physiotherapist) / Finansowanie } \\
\text { pracownikom leczenia lub rehabilitacji (np. u kardiologa, dentysty, fizjoterapeuty) }\end{array}$ & 25 & 29 \\
\hline
\end{tabular}


Table 3. Non-mandatory health-oriented actions in companies in 2006 and 2010 - cont.

Tabela 3. Nieobligatoryjne działania prozdrowotne w firmach w latach 2006 i 2010 - cd.

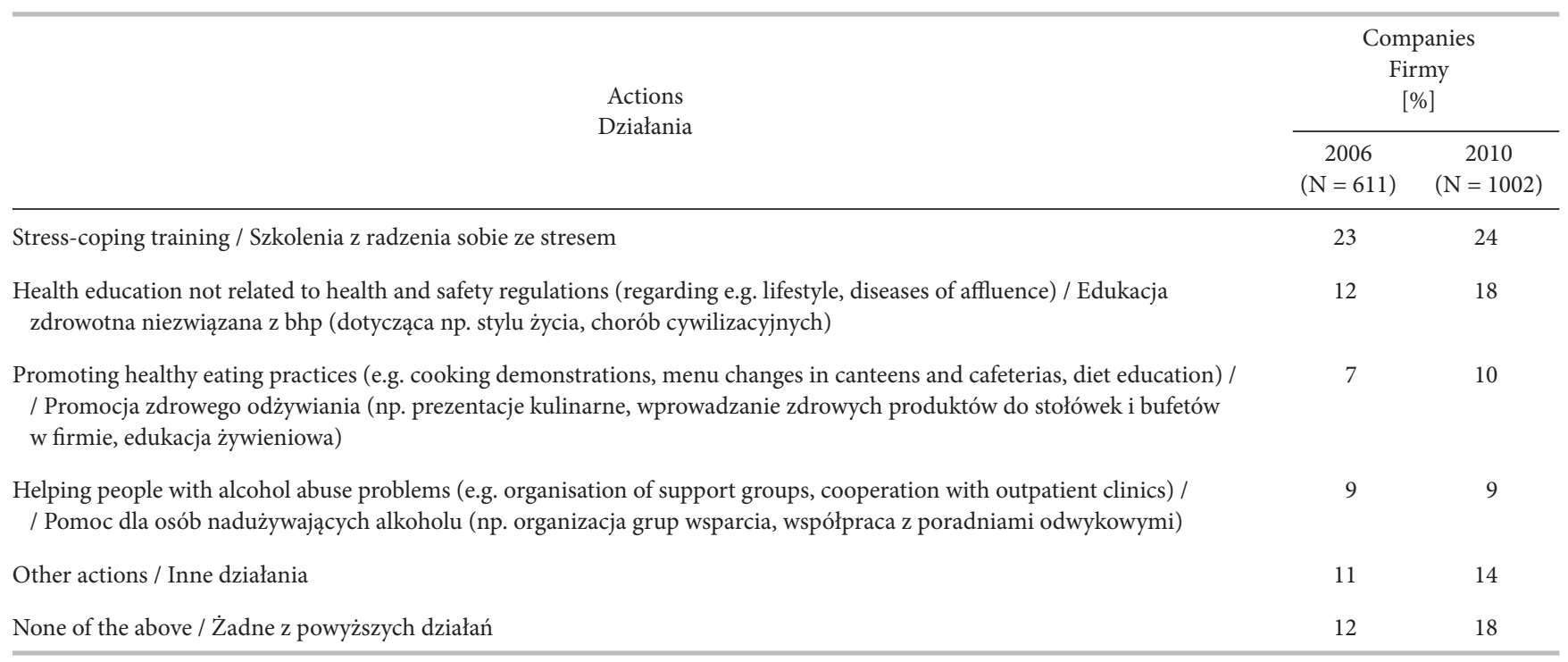

companies'. Apparently, the number of organisations (88\% in 2006 and $82 \%$ in 2010) indicating various targeted initiatives was much higher than those declaring this earlier in general terms (cf. Table 1).

In both surveys, the frequency with which most mentioned activities are implemented, as well as their classification in this respect, turns out to be similar. Companies put major effort in enhancing their physical work environments and organising health services and

${ }^{1}$ Among these, the paper does not discuss anti-smoking campaigns, as they were discussed in detail in another publication (17). sports classes, and seek to reduce their employees' adverse stress levels. A closer comparison of data for the years 2006 and 2010 reveals an increase by over 10 percent in the group of companies which engage in improving the characteristics of common areas and the health-related parameters of workplaces. These activities are now the most frequently indicated elements of health promotion and this might be the main area in which the companies declare their increased involvement. This increase may also result from a slightly more frequent implementation of most other initiatives.

Table 4. Health-oriented actions in 2010 and financial soundness and the level of employment in the company Tabela 4. Działania prozdrowotne w 2010 r. a kondycja ekonomiczna firmy i wielkość zatrudnienia

\begin{tabular}{|c|c|c|}
\hline \multirow{2}{*}{$\begin{array}{c}\text { Actions } \\
\text { Działania }\end{array}$} & \multicolumn{2}{|c|}{$\begin{array}{l}\text { Companies }^{*} \\
\text { Firmy }^{*} \\
(\mathrm{~N}=1002)\end{array}$} \\
\hline & $\begin{array}{c}\text { financial } \\
\text { soundness } \\
\text { kondycja } \\
\text { ekonomiczna }\end{array}$ & $\begin{array}{c}\text { level of } \\
\text { employment } \\
\text { wielkość } \\
\text { zatrudnienia }\end{array}$ \\
\hline $\begin{array}{l}\text { Attention to visual appearance, comfort and access to common areas (canteens, toilets etc.) significantly exceeding } \\
\text { current standards and renovations / Dbałość o estetykę, wygodę i dostępność pomieszczeń socjalnych } \\
\text { (jadalni, łazienek itp.) znacząco wybiegająca ponad obowiązujące normy oraz bieżące remonty }\end{array}$ & $\begin{array}{c}\mathrm{p}<0.02 \\
\chi^{2}=14.61\end{array}$ & $\begin{array}{l}p<0.0000 \\
\chi^{2}=29.67\end{array}$ \\
\hline $\begin{array}{l}\text { Health-oriented job modifications exceeding health and safety regulations (e.g. reducing noise levels to that } \\
\text { significantly below the norm) / Poprawa warunków zdrowotnych na stanowiskach pracy ponad wymagania } \\
\text { przepisów bhp (np. redukcja hałasu znacząco poniżej normy) }\end{array}$ & $\begin{array}{c}\mathrm{p}<0.01 \\
\chi^{2}=16.17\end{array}$ & $\begin{array}{l}\mathrm{p}<0.002 \\
\chi^{2}=20.75\end{array}$ \\
\hline Vaccinations (e.g. influenza and hepatitis) / Szczepienia, np. przeciw grypie, wirusowemu zapaleniu wątroby & $\begin{array}{l}\mathrm{p}<0.0003 \\
\chi^{2}=25.25\end{array}$ & $\begin{array}{l}\mathrm{p}<0.0007 \\
\chi^{2}=23.22\end{array}$ \\
\hline Organising sports activities for employees / Organizowanie zajęć sportowych dla pracowników & $\begin{array}{l}\mathrm{p}<0.0000 \\
\chi^{2}=51.26\end{array}$ & $\begin{array}{l}\mathrm{p}<0.0000 \\
\chi^{2}=55.50\end{array}$ \\
\hline
\end{tabular}


Table 4. Health-oriented actions in 2010 and financial soundness and the level of employment in the company - cont. Tabela 4. Działania prozdrowotne w 2010 r. a kondycja ekonomiczna firmy i wielkość zatrudnienia - cd.

\begin{tabular}{|c|c|c|}
\hline $\begin{array}{l}\text { Actions } \\
\text { Działania }\end{array}$ & \multicolumn{2}{|c|}{$\begin{array}{l}\text { Companies }^{*} \\
\text { Firmy } \\
(\mathrm{N}=1002)\end{array}$} \\
\hline $\begin{array}{l}\text { Changes in organisation and management to reduce work-related stress / Zmiany w organizacji i zarządzaniu mające } \\
\text { na celu zmniejszenie poziomu stresu w pracy }\end{array}$ & $\begin{array}{c}\mathrm{p}<0.01 \\
\chi^{2}=15.31\end{array}$ & $\begin{array}{l}\mathrm{p}<0.0008 \\
\chi^{2}=22.81\end{array}$ \\
\hline $\begin{array}{l}\text { Treatment or rehabilitation services funded by the company (e.g. cardiologist, dentist, physiotherapist) / Finansowanie } \\
\text { pracownikom leczenia lub rehabilitacji (np. u kardiologa, dentysty, fizjoterapeuty) }\end{array}$ & $\begin{array}{l}\mathrm{p}<0.002 \\
\chi^{2}=20.69\end{array}$ & $\begin{array}{l}\mathrm{p}<0.0000 \\
\chi^{2}=39.32\end{array}$ \\
\hline $\begin{array}{l}\text { Health education not related to health and safety regulations (regarding e.g. lifestyle, diseases of affluence) / Edukacja } \\
\text { zdrowotna niezwiązana z bhp (dotycząca np. stylu życia, chorób cywilizacyjnych) }\end{array}$ & n.s. & $\begin{array}{l}\mathrm{p}<0.0001 \\
\chi^{2}=27.12\end{array}$ \\
\hline $\begin{array}{l}\text { Promoting healthy eating practices (e.g. cooking demonstrations, menu changes in canteens and cafeterias, diet } \\
\text { education) / Promocja zdrowego odżywiania (np. prezentacje kulinarne, wprowadzanie zdrowych produktów } \\
\text { do stołówek i bufetów w firmie, edukacja żywieniowa) }\end{array}$ & $\begin{array}{c}\mathrm{p}<0.03 \\
\chi^{2}=13.42\end{array}$ & $\begin{array}{l}\mathrm{p}<0.006 \\
\chi^{2}=18.05\end{array}$ \\
\hline $\begin{array}{l}\text { Helping people with alcohol abuse problems (e.g. organisation of support groups, cooperation with outpatient clinics) / } \\
\text { / Pomoc dla osób nadużywających alkoholu (np. organizacja grup wsparcia, współpraca z poradniami odwykowymi) }\end{array}$ & n.s. & $\begin{array}{l}\mathrm{p}<0.0000 \\
\chi^{2}=28.25\end{array}$ \\
\hline Other actions / Inne działania & $\begin{array}{l}\mathrm{p}=0.005 \\
\chi^{2}=18.09\end{array}$ & $\begin{array}{c}\mathrm{p}<0.001 \\
\chi^{2}=21.67\end{array}$ \\
\hline
\end{tabular}

$* \mathrm{df}=6$.

n.s. - not significant / nieistotne statystycznie.

The companies undertake activities with a varied frequency, depending on their financial soundness and the number of employees (Table 4).

Inasmuch as among entities which perceive their financial soundness as very good, only one in nine does not implement any of the activities indicated in the question, in the group of those worse off this proportion grows to one in four (although statistically insignificant, this interrelation still merits attention).

Companies which enjoy the best financial soundness, as compared to those perceiving their situation as bad, are seven times more likely to implement healthy nutrition programmes, and three times more likely to organise sports classes for their employees. They will also twice as often introduce organisational changes aimed at reducing stress and instruct their personnel how to deal with it. They fund medical services and preventive checkups and are more keen on implementing other related initiatives (even if some of these interrelations are not statistically significant). Although the differences are especially evident between organisations on the two extreme ends as regards their perceived situation, in most of the activities discussed a clear trend can be noticed - an increase in the company's wealth is accompanied by a systematic growth in the number of health-oriented activities (only with regard to employer's attention to common areas, sanitary conditions at workstations, stress-reducing changes in organisation, and help offered to persons abusing alcohol is this trend very slight or not noticeable whatsoever).

The level of employment seems to be a factor more prone to affect the prevalence of these health-oriented practices. The larger the company, the more significantly often it undertakes each of the discussed activities. A systematic increase involves the organisation of sports activities, non-mandatory medical examinations, training in 
stress management, treatment and rehabilitation services, enhanced quality of common areas, employee vaccinations, stress-related modifications to work environment and the promotion of healthy nutrition. In the remaining aspects (health education, help to persons abusing alcohol, and health-oriented modifications of work stations), there are marked differences between the smallest and the largest companies, although those tend to fade in intermediary categories. Furthermore, inasmuch as no such activities are undertaken in $27 \%$ of the smallest entities, among those largest, this equals only $2 \%$.

\section{The reasons for companies' involvement in health promotion}

Grounds substantiating the implementation of healthpromotion activities are presented in Table 5. For each reason listed in the questionnaire questions, respondents from entities active in this field assessed whether it motivated their company to expend health-oriented efforts.

Health-oriented activities in companies usually result from two groups of reasons. The first includes business considerations - hoping that health promotion will aid reducing costs and boosting the enterprise's productivity and image, i.e. improve its general market position. The second deals with the attitudes of the employer and/or the company's management staff - their determination to protect and look after their employees' health. In addition, irrespective of the above considerations, nearly $2 / 3$ of companies conduct health-oriented activities as if by force of inertia, not wishing to resign from a state of affairs developed over many years.

Table 5. The reasons for health-oriented actions in companies in 2006 and 2010

Tabela 5. Powody działań prozdrowotnych podejmowanych w firmach w latach 2006 i 2010

\begin{tabular}{|c|c|c|}
\hline $\begin{array}{c}\text { Reason } \\
\text { Uzasadnienie }\end{array}$ & \multicolumn{2}{|c|}{$\begin{array}{l}\text { Companies } \\
\text { Firmy } \\
{[\%]}\end{array}$} \\
\hline $\begin{array}{l}\text { The actions are undertaken due to the fact that the employer wants to take good care of its employees' health / Działania } \\
\text { podejmowane są dlatego, że pracodawca chce dobrze zadbać o zdrowie swoich pracowników }\end{array}$ & 86 & 85 \\
\hline $\begin{array}{l}\text { The actions are undertaken to build social relationships within the company and to improve its employees' morale / Działania } \\
\text { podjęto, żeby budować relacje społeczne wewnątrz firmy i morale pracowników }\end{array}$ & 61 & 69 \\
\hline $\begin{array}{l}\text { The actions are undertaken to increase efficiency, and to improve the quality of production or services / Działania podjęto, } \\
\text { żeby zwiększać wydajność, poprawiać jakość produkcji lub usług }\end{array}$ & 61 & 67 \\
\hline $\begin{array}{l}\text { The actions are mainly the result of the commitment and passion of internal specialists within the company e.g. from the } \\
\text { health and safety, medical or social departments / Działania to głównie efekt zaangażowania i pasji kogoś z wewnętrznych } \\
\text { specjalistów, np. działu bhp, medycznego, socjalnego }\end{array}$ & 32 & 53 \\
\hline $\begin{array}{l}\text { The actions are undertaken to create a good public image of the company among its customers, partners and associates / } \\
\text { / Działania podjęto w celu budowania dobrego publicznego wizerunku firmy wśród jej klientów, partnerów, kooperantów }\end{array}$ & 45 & 48 \\
\hline $\begin{array}{l}\text { The actions result from the corporate policy of our company / Działania wynikają z polityki korporacyjnej, której podlega } \\
\text { nasza firma }\end{array}$ & 27 & 27 \\
\hline $\begin{array}{l}\text { We received a profitable offer from someone who carries out such actions in the workplace / Dostaliśmy z zewnątrz korzystną } \\
\text { ofertę od kogoś, kto realizuje takie działania w zakładach pracy }\end{array}$ & 21 & 17 \\
\hline
\end{tabular}


In comparison to 2006, the vast majority of motives have become more prevalent. All of the businessbased arguments gained in importance (each by several points), with a particular increase in the number of respondents who indicated personal involvement in health promotion by the company's management or health experts (a 20-point increase in each of these motives). A much lower prevalence can be observed in the treatment of health-oriented activities as a form of non-financial incentives for employees (a drop by 20 points).
In several cases, the frequency of providing reasons for health-oriented activities differed due to the varied levels of companies' financial soundness, while in several others, due to the level of employment, and not always the same reasons were provided. Moreover, some of the reasons were independent of these two variables (Table 6).

Financial soundness shows a poor differentiation capacity as regards the cited reasons; however, the wealthier the company, the more likely it is to provide extended argumentation. Along with the higher assessment of

Table 6. The financial soundness and level of employment in company vs. the reasons for the implementation of non-mandatory health-oriented actions in 2010 among the companies involved in health promotion

Tabela 6. Kondycja ekonomiczna firmy i wielkość zatrudnienia a powody podjęcia nieobligatoryjnych działań prozdrowotnych w 2010 r. w firmach realizujących promocję zdrowia

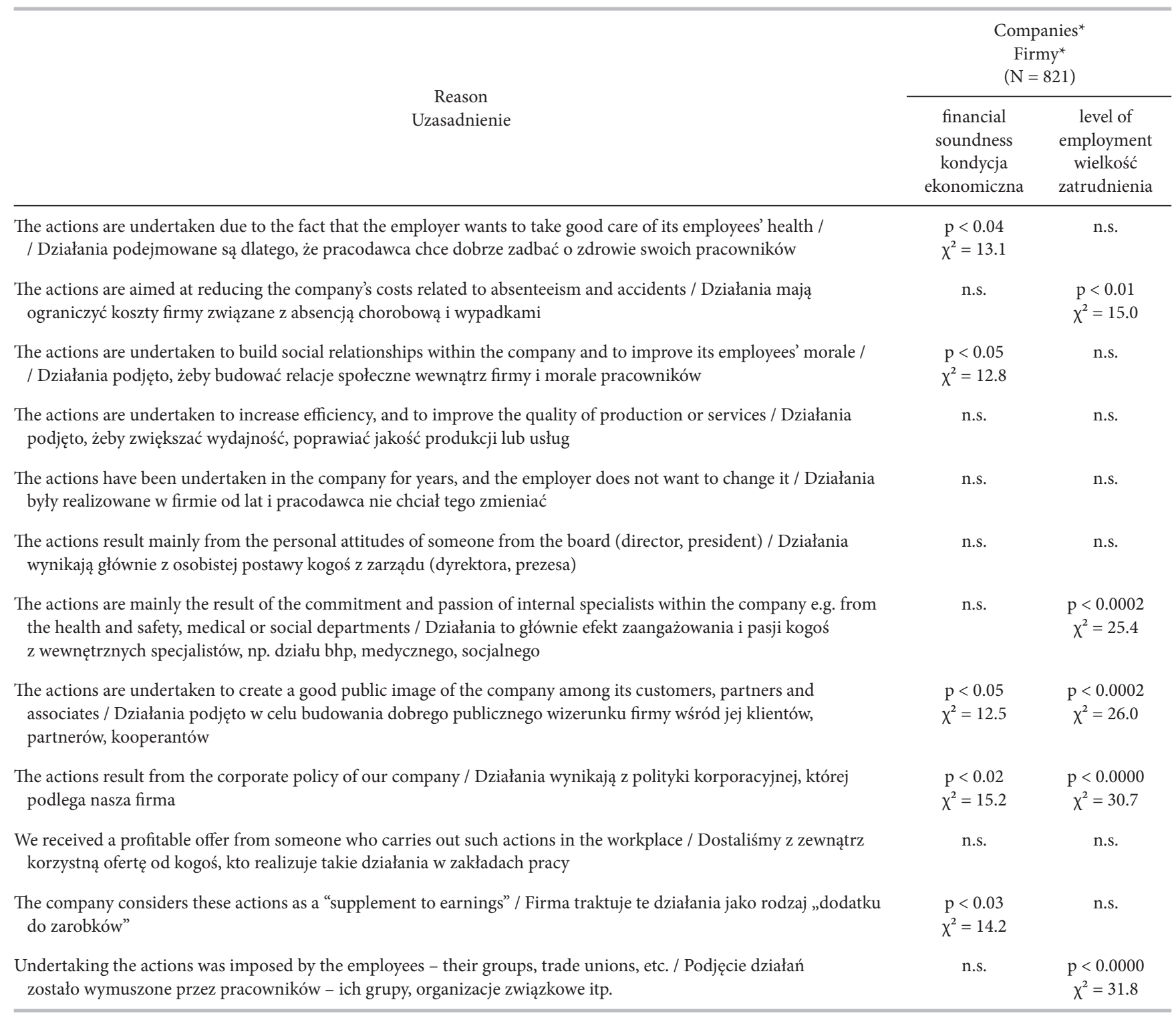

Abbreviations as in Table 4 / Objaśnienia jak w tabeli 4. 
their financial soundness, companies have a greater tendency to state that their health-oriented activities arise from the applicable corporate policies, i.e. imposed values, principles, norms or operating rules binding for the entire corporation. This motive was cited twice as often (40\%) in the wealthiest workplaces as in those poorest (19\%). In addition, the former of these entities are slightly more likely to argue that the employer wants to provide good care over the health of its personnel ( $88 \%$ and $70 \%$ respectively), that they undertake healthoriented activities to improve social relations and boost morale among their employees (79\% and 55\%), to build a favourable public image ( $62 \%$ and $40 \%$ ), and that they treat such activities as a form of non-financial incentive (24\% and 13\%). Other motives are rather independent of companies' financial soundness.

In comparison to the financial soundness of an organisation, its size has a stronger differentiation impact on the motives of health-oriented activities. The larger (and wealthier) the company, the more reasons it usually has to become involved in health promotion. Especially noticeable is the difference between the smallest and the largest entities. The latter tend to substantiate health promotion activities with their corporate policies (this motive was mentioned by one in four among the smallest companies, and every second among the largest) and the wish to build a good public image (36\% among the smallest and $71 \%$ among the largest companies), pressure from the personnel (a motive present in every tenth small and every fourth large entity), a committed attitude of internal health experts (45\% and 67\% respectively) and the wish to reduce employee absence costs ( $73 \%$ and $94 \%$ respectively).

\section{Obstacles to health promotion}

The problems encountered by workplaces in implementing health-promotion programmes are presented in Table 7. Limited funds for this purpose and little interest of the personnel were usually mentioned. A fact worth noting is that one in four-five companies did not report any problems in this field.

Since 2006, a slight growth has been recorded in the number of entities indicating some difficulties. Admittedly, slightly fewer companies complained about deficiencies in the systemic solutions aimed at health promotion and the fact of their management staff being more absorbed with objectives other than health. At the same time, however, an increase occurred in the percentage of workplaces which indicated employees' poor interest in health promotion at work.

Table 7. The main obstacles in the implementation of non-mandatory actions promoting health in 2006 and 2010

Tabela 7. Główne utrudnienia w realizacji nieobligatoryjnych działań prozdrowotnych w latach 2006 i 2010

\begin{tabular}{|c|c|c|}
\hline \multirow{2}{*}{$\begin{array}{l}\text { Obstacle* }^{*} \\
\text { Utrudnienie }^{*}\end{array}$} & \multicolumn{2}{|c|}{$\begin{array}{c}\text { Companies } \\
\text { Firmy } \\
{[\%]}\end{array}$} \\
\hline & $\begin{array}{c}2006 \\
(\mathrm{~N}=600)\end{array}$ & $\begin{array}{c}2010 \\
(\mathrm{~N}=1002)\end{array}$ \\
\hline Limited financial resources for these kind of actions / W firmie nie ma środków finansowych na tego typu cele & 39 & 40 \\
\hline Little interest of employees regarding health issues / Małe zainteresowanie pracowników takimi działaniami & 24 & 31 \\
\hline $\begin{array}{l}\text { Lack of legal and fiscal regulations that would encourage companies to increase their concern about the health of their } \\
\text { personnel / Niedostatek rozwiązań prawnych i fiskalnych, które zachęcałyby firmy do zwiększonej troski o zdrowie personelu }\end{array}$ & 28 & 18 \\
\hline Lack of good outside offer to carry out this type of services / Brak dobrej zewnętrznej oferty na wprowadzenie tego typu usług & 14 & 14 \\
\hline $\begin{array}{l}\text { Preoccupation of management staff with the implementation of other important objectives / Zaabsorbowanie kadry } \\
\text { zarządzającej realizowaniem innych ważnych celów }\end{array}$ & 17 & 11 \\
\hline $\begin{array}{l}\text { Lack of information and materials about the importance of these actions for the company / Niedostatek informacji i materiałów } \\
\text { na temat znaczenia takich działań dla firmy }\end{array}$ & 11 & 10 \\
\hline $\begin{array}{l}\text { Lack of employees who are capable of organising such actions well / Brak w przedsiębiorstwie osób, które dobrze zorganizują } \\
\text { takie działania }\end{array}$ & 8 & 9 \\
\hline Other obstacles / Inne utrudnienia & 1 & 2 \\
\hline The company does not encounter any obstacles / Przedsiębiorstwo nie napotyka żadnych przeszkód & 28 & 22 \\
\hline
\end{tabular}

* Three choices from the list were allowed / Z listy można było wybrać 3 pozycje. 
The better the companies' financial soundness, the more systematically they declare no difficulties in implementing health promotion - in the wealthiest group, their increased prevalence was not observed in every fourth entity, against as few as one in thirteen among the entities which reported bad economic standing $\left(\chi^{2}=19.9 ; \mathrm{p}<0.0002\right)$. The only single obstacle, with regard to which substantial differences in perception were observed in relation to the company's economic standing, was - and this might seem obvious ${ }^{2}$ - the lack of funds for health-oriented activities. This applies to $17 \%$ workplaces with a very good financial standing and to $75 \%$ of those assessing it as poor $\left(\chi^{2}=99.3\right.$; $\left.p<0.0000\right)$.

The level of employment does not differentiate indications of obstacles in health-oriented activities. An increase in the level of employment is accompanied by a very weak tendency to more often complain about limited funds $\left(\chi^{2}=9.5 ; p<0.02\right)$. This is a surprising finding, as large companies usually enjoy better financial situation, and assessing it as good, as shown above, is not conducive to indicating the obstacle in question.

\section{OVERVIEW}

In the current circumstances, with insufficient political and systemic support, health promotion in workplaces in Poland is dependent on two main factors. The first and perhaps the more important is the awareness among the management staff as to the fact that since employees' health is not their solely private affair and a public good, but also the company's capital, it is worth being invested in, instead of just being protected to the extent required by the law. The second factor involves the companies' economic situation which should allow them to not only devote their own funds to health-oriented activities (as these outlays don't need to be exorbitant), but to think of prospective goals, rather than focus on the current market survival, often at the cost of personnel exploitation.

The second half of the previous decade, i.e. the period to which the presented findings directly apply, was a prosperous time for the Polish economy. Nearly $2 / 3$ of the surveyed companies (3/4 in 2006) assessed their financial situation as good. It can be, thus, assumed that economic factors contributed to the promotion of health

\footnotetext{
${ }^{2}$ Some of the health-oriented activities discussed here do not necessarily entail additional outlays for the company, but are limited to e.g. reallocating funds or changing approaches towards employees. Consequently, these indications should be understood not as a mere description of the company's general situation, but rather as a reflection of its adopted approach to the issue of its personnel's health.
}

in most workplaces. Similarly, the awareness a mong most managers - at least in general and declarative terms also seemed to favour health-oriented activities.

Around $40 \%$ of the respondents generally declared that their companies were more attentive about their personnel's health than it is required by the law; at the same time, twice as many organisations (88\% in 2006 and $82 \%$ in 2010) indicated various specific health-promotion activities. This discrepancy in findings can be explained by the fact that the respondents could have interpreted the phrase "health-oriented activities" in the general question in a more narrow sense than the scope of such activities presented in the detailed questions (as a list ${ }^{3}$ ). It is possible that some of them (e.g. pertaining to work environment) were not initially perceived as health-related. It may also be that some of the indicated detailed activities are conducted in an occasional and cursory manner, which is why respondents did not take them into account while answering the first general question. Observations on the quality of healthoriented activities at workplaces $(7,17,18)$ seem to support such an explanation. It is often the case that the undertaken activities do not result from a thorough assessment, nor are they based on clearly formulated corporate policies and implementation plans. They are also rarely evaluated, although all of these factors facilitate a systematic and long-term implementation of health promotion in work environments.

Although in the years 2006-2010 the number of companies which declared themselves as being active in the field of health promotion remained stable (with a slight drop, where specific activities were to be indicated), the general climate for deploying such non-mandatory health-oriented activities in the analysed organisations had improved. In 2010, 31\% of the surveyed companies assessed their involvement in health promotion to be deeper than a few years earlier (26\% in the previous survey). More entities also declared ( $31 \%$ against $20 \%$ in the previous survey) that they had adopted formalised, internal policies in respect of personnel health, which increased their chances of implementing a broader scope of health-oriented activities in relation to those required by the law. Moreover, managers more often expressed the belief that health

\footnotetext{
${ }^{3}$ The general declaration that a company conducts non-mandatory healthoriented activities showed the strongest statistical correlation with the provision of vaccinations to employees $\left(\chi^{2}=165.09 ; \mathrm{p}<0.0000\right)$, additional preventive checkups $\left(\chi^{2}=128.84 ; \mathrm{p}<0.0000\right)$, funding medical services $\left(\chi^{2}=112.82 ; \mathrm{p}<0.0000\right)$ and the organisation of sports activities $\left(\chi^{2}=88.88\right.$; $\mathrm{p}<0.0000)$, and other activities not mentioned in the questionnaire $\left(\chi^{2}=105.13 ; \mathrm{p}<0.0000\right)$.
} 
promotion had a beneficial impact on the company's operation. Among the reasons for implementing nonmandatory health-oriented activities in 2010, all types of business-oriented arguments were more prevalent. As regards motives for the undertaken activities, a substantial increase was observed in the number of indications of the personal involvement of the management staff or health experts in health promotion (by nearly 20 points for each of these aspects).

On the other hand, in comparison with 2006, a slight growth was recorded in the number of entities indicating some difficulties in the discussed health-oriented activities. Admittedly, slightly fewer companies complained about deficiencies in the systemic solutions aimed at health promotion and the fact of their management staff being more absorbed with objectives other than health. At the same time, however, an increase occurred in the percentage of workplaces which indicated employees' poor interest in health promotion at work. This problem was the second most prevalent response, right after limited funds available to companies for health promotion. The fact of these obstacles being particularly stressed by the respondents might seem concerning, especially set against the current economic crisis.

The collected findings have in many aspects demonstrated that the more positive companies are about their situation, the more systematically they conduct non-mandatory health-oriented activities. They also more often declare broader involvement in healthrelated issues now than several years ago. This seems to confirm the objective significance of the economic factor, while highlighting needs as to the dissemination of information on the costs of health promotion - the costs incurred for promotion (which may be low), but first and foremost returns on this type of investments. The profitability of health promotion is confirmed by data from developed countries, although no findings in this respect are available for Polish companies. This raises the issue of the quality of implementations, as not all of the activities of this type generate tangible effects.

Companies' involvement in health promotion is also associated with the level of employment - the larger the company, the more likely it is to pursue activities in this field (as seen especially in the largest entities). At the same time, such companies are more often convinced that their activities have intensified and have more reasons to pursue health promotion. Large companies more often undertake planned activities set out in their internal organisational policies. This is also corroborated by other studies (18). The aforementioned dissimilarities connected with the size of a workplace seem to be even more manifest than those arising from a different financial standing.

The presented findings did not reveal which mechanisms make good financial soundness and high employment level conducive to the non-mandatory health-oriented activities of companies. Besides aspects of an objective nature (available funds, well-developed internal health management structures, etc.), other factors are of importance here, such as the company's organisational culture, as well as those embedded in the managers' attitudes and action strategies. This subject definitely merits elaboration in further studies.

Notwithstanding all of the variations, it is noteworthy that most companies put effort in enhancing their physical work environments and organising and/or funding health services and sports classes, as well as seek to reduce their employees' adverse stress levels. Many activities, including those not required by the law, regard smoking (17). A detailed analysis of the latter shows that the majority of companies confine themselves to the simplest, loosely coordinated, and usually not the most effective solutions. By analogy, one could assume that this regularity extends over the remaining areas of activity.

\section{CONCLUSIONS}

1. From the mid-2000s until the end of that decade, an increase in awareness was observed among managers in medium-sized and large workplaces as to the benefits that health promotion could bring to their companies. Nearly $40 \%$ of companies were concerned about their personnel's health to a greater extent than it is required by the law. At the same time, a more numerous group implemented various activities in this field (especially aimed at improving their physical work environments) without any health-related intentions and often on an occasional basis. Another increase was recorded among entities which declared their activities in the sphere of health promotion to be broader than several years earlier. These phenomena may be interpreted as a foretoken of a further development of health promotion in workplaces and an increased demand for professional services in this area.

2. The factors conducive to health-oriented activities undertaken beyond legal obligations include the good financial standing of a workplace and the high level of employment. The mechanisms behind 
this interrelation have not been fully explored yet. Another observation is that a period of prosperity seems to be beneficial to the companies' involvement in health promotion. Currently, however, there is no data which could confirm this and allow an estimation of whether economic crises lead to an opposite effect and if so, to what degree. These issues require further analysis.

3. The current state of affairs regarding health promotion in small workplaces (with fewer than 50 employees) has not been systematically characterised. If - as suggested by the findings - a lower level of employment entails companies' weaker involvement in the discussed area, the smallest (not analysed) entities should be expected to engage in even less activity. There is a need to undertake research on this issue.

4. The observed differences in the companies' activities in personnel health promotion might result in the emergence and intensification of social health inequalities. The personnel employed in the wealthiest and largest companies more often receive additional health-oriented assistance, as compared to those employed in smaller companies, with a worse financial soundness (which is often accompanied by poorer work conditions, lower wages and obligatory healthcare standards, etc.) This problem merits being taken into account in the national healthcare policy.

\section{REFERENCES}

1. World Health Organization: Healthy workplaces: A model for action. For employers, workers, policymakers and practitioners. Geneva: WHO; 2010.

2. Puchalski K, Korzeniowska E. [Workplace health promotion in public health policies in Poland]. Med Pr. 2008;5(1):55-64. Polish.

3. Rantanen J, Kim R. Situation analysis and recommendations for stewardship on workplace health promotion in Poland. Copenhagen: WHO Regional Office for Europe; 2012.

4. Berry L, Marabito AM, Baun WB. [What's the hard return on employee wellness programs?]. Harvard Business Rev Polska. 2012;115:114-25. Polish.

5. Hamalainen RM. Workplace health promotion in Europe - The role of national health policies and strategies. Helsinki: Finnish Institute of Occupational Health; 2007.

6. De Greef M, de Broeck V, de Beeck RO, van den Broek K, Wlodarski K, editors. The quality of working life: challenges for the future. Brussels: Prevent; 2007.
7. Puchalski K, Korzeniowska E. [An attempt to evaluate the quality of workplace health promotion against its requirements]. Med Pr. 2003;54(1):1-7. Polish.

8. Pyżalski J, Puchalski K, Korzeniowska E. [Workplace mental health promotion in Poland]. In: Okulicz-Kozaryn K, Ostaszewski K, editors. [Mental health promotion, research and activities in Poland]. Warszawa: Institute of Psychiatry and Neurology; 2008, p. 33-51. Polish.

9. Korzeniowska E. Workplace health promotion in Poland. Barents Newsletter Occupational Health Safety. 2013;16(1):21.

10. Goszczyńska E. [Activities of voivodeship occupational medicine centers in workplace health promotion in 2008]. Med Pr. 2010;61(3):353-65. Polish.

11. Pyżalski J, Wojtaszczyk P. [Activities of occupational medicine physicians in the area of workplace health promotion]. Med Pr. 2004;55(3):227-32. Polish.

12. Puchalski K, Korzeniowska E, Iwanowicz E. [Attitudes of occupational medicine nurses toward workers' health promotion]. Med Pr. 2007;58(6):485-99. Polish.

13. Breucker G, Sochert R. Health employees in health enterprises the European Network for Workplace Health Promotion. In: Korzeniowska E, Puchalski K, editors. Workplace health promotion in enlarging Europe. Łódź: Nofer Institute of Occupational Medicine; 2006, p. 9-22.

14. Gniazdowski A. [The role of the occupational medicine physician in workplace health promotion]. In: Krasucki P, Kuczkowska-Dominas H, editors. [Occupational medicine for general practitioners]. Script. Part 2. Warszawa: Centrum Medyczne Kształcenia Podyplomowego; 1998, p. 199-214. Polish.

15. Puchalski K, Korzeniowska E. [Structure, strategies and methodology of teachers mental health promotion program]. In: Pyżalski J, Merecz D, editors. [Psychosocial work conditions of Polish teachers. Between burnout and engagement]. Kraków: Oficyna Wydawnicza Impuls; 2010, p. 133-55. Polish.

16. Ministry of Economy. [Poland 2006. Economy Report]. Warszawa 2006 [cited 2013 May 16]. Available from: http://www.mg.gov.pl/NR/rdonlyres/C14A5DE8-7236-4770A72D-44D7A0454F93/31029/raportostaniegospodarki.pdf. Polish.

17. Puchalski K, Korzeniowska E. Actions reducing tobacco smoking at the workplace - do larger and richer companies solve the problem better? Med Pr. 2012;63(3):257-70.

18. Juszczyk G, Pergoł M, Olejniczak D, Walewska-Zielecka B, Ślusarczyk J. [Study on engagement in health promotion at the workplace of non-public health providers in Poland]. Przegl Epid. 2012;66:547-54. Polish. 